\title{
The Joint Chiefs of Staff, the atom bomb, the American military mind and the end of the Second World War
}

\author{
Phillips Payson O’Brien
}

\begin{tabular}{|c|c|}
\hline Date of deposit & 18012019 \\
\hline Document version & Author's accepted manuscript \\
\hline Access rights & $\begin{array}{l}\text { Copyright (c) } 2019 \text { Informa UK Limited, trading as Taylor \& } \\
\text { Francis Group. This work is made available online in accordance } \\
\text { with the publisher's policies. This is the author created, accepted } \\
\text { version manuscript following peer review and may differ slightly } \\
\text { from the final published version. }\end{array}$ \\
\hline $\begin{array}{l}\text { Citation for } \\
\text { published version }\end{array}$ & $\begin{array}{l}\text { O'Brien, P. (2019). The Joint Chiefs of Staff, the atom bomb, the } \\
\text { American military mind and the end of the Second World War. } \\
\text { Journal of Strategic Studies, Latest Articles }\end{array}$ \\
\hline $\begin{array}{l}\text { Link to published } \\
\text { version }\end{array}$ & https://doi.org/10.1080/01402390.2018.1559150 \\
\hline
\end{tabular}

Full metadata for this item is available in St Andrews Research

Repository at: https://research-repository.st-andrews.ac.uk/

\section{St Andrews Research Repository}




\section{The Joint Chiefs of Staff, the Atom Bomb, the American Military Mind and the End of the Second World War}

The Second World War witnessed the most famous and controversial ending of any conflict in human history. The decision by the United States government to drop uranium and plutonium, fissionbased weapons (better known as atomic bombs) on the Japanese cities of Hiroshima and Nagasaki makes its ending seminal. From the moment the bombs exploded there has been a debate, which shows no sign of abating, about the decision to cross the atomic threshold; whether the act was necessary, ethical, or even counter-productive. A multitude of books and articles have been written on the subject that go back and forth over the question of whether this was the best way to achieve victory. ${ }^{1}$

This article will not rehash those arguments. What it aims to do, however, is examine one particular set of views, in many ways the most surprising-that of the top of the US strategic command, the Joint Chiefs of Staff (JCS). This group of two army generals and two navy admirals, all profoundly conventional, Caucasian, Christian, educated in military academies, born and raised in middle-class households-had a more complex set of ethical and strategic responses to the use of atomic weapons than one might assume. Looking at the range of their views on the issue of the atom bomb provides an important insight into how they viewed victory, the meaning of the Second World War and the state of the American military mind.

The Joint Chiefs of Staff were the four most important military officers in the United States during the Second World War; Admiral William Leahy Chief of Staff to the President and Chairman of the joint chiefs, General George Marshall Chief of Staff of the Army, Admiral Ernest King Chief of Naval Operations, and General Henry (Hap) Arnold Chief of Staff of the Army Air Force. ${ }^{2}$ Collectively they were Franklin Roosevelt's and Harry Truman's highest ranking military advisers. Leahy was one of Roosevelt's oldest friends in Washington, the two had become close in 1913 when they first met in the Navy Department. Marshall, King and Arnold had more professional relationships with the president and this made a material difference over the eventual decision to use the atomic bomb. While Roosevelt lived, Leahy had great influence over the president, particularly as time went on and Roosevelt weakened. After Roosevelt's death in April 1945, however, things changed. Truman was an 
army man by background and esteemed George Marshall in particular.. The shift would prove to be important as Leahy and Marshall's views on the atom bomb diverged the most as time went by.

The other two joint chiefs, King and Arnold, were less involved in the ultimate decision of whether and how to use the atom bomb. King was handicapped by the fact that the development of the atom bomb through the Manhattan Project, was an Army programme. ${ }^{3}$ As such Arnold, who as the head of the air force, though actually still under Marshall who was head of the army, could have tried to play an important role in determining atomic policy, was somewhat passive on the issue. His reluctance to get involved came at least partly from his poor health (Arnold had a number of major heart attacks during the war).

The first thing that must be understood about the joint chiefs was that they were less important than the civilian leadership in making the final decision to drop the atom bomb. While Roosevelt had been alive, he kept such important decisions very close to his chest, often deciding things using only the joint chiefs with Harry Hopkins. Truman, on the other hand, feeling a little unsure and wanting very much to act in what he thought was Roosevelt's spirit (but which decidedly was not) delegated a great deal of authority in the first few months of his Interim Committee to decide on the best way forward. ${ }^{4}$ Composed of government officials and scientists, the committee was chaired by Secretary of War Henry Stimson and, crucially, included James Byrnes as Truman's personal representative. For Stimson this was represented a temporary increase in influence. While Roosevelt lived, the president had kept the elderly Republican away from many of the crucial meeting of the war. Stimson had, for instance, not been included in the grand-strategic conferences in Casablanca, Quebec (both first and second), Cairo, Tehran and Yalta-conferences which determined the strategy of the war and set many of conditions that were supposed to govern the peace afterwards. Truman, however, allowed the secretary of war to have some influence over important decisions such as the atom bomb. ${ }^{5}$ However even more than Stimson, the real beneficiary of the Interim Committee's establishment was Byrnes. Roosevelt had been growingly increasingly irritated with Byrnes and just before FDR died, the South Carolinian was leaving his important position as head of the Office of Economic Stabilization. Truman, however, leaned heavily on Byrnes, whom he had originally thought Roosevelt would select to be the new vice president in 1944. Not only did he make Byrnes his personal representative on the Interim Committee, in late June 1945 he would soon make him the new secretary of state, when the incumbent, Edward Stettinius, resigned.

The influence of Stimson and Byrnes mattered greatly as the former was mostly supportive of using the atomic bomb while the latter was enthusiastically supportive, and this made the formation of the interim committee vital. During the meeting of the committee on 31 May 1945, Stimson, who 
was honestly torn about the meaning of the bomb endorsed the use of the atomic bomb against Japan without warning. ${ }^{6}$ However he made a contradictory claim that while the attack should not 'concentrate' on a civilian area, an area of war industry closely surrounded by workers houses was the most 'desirable target."7 Byrnes had no such qualms. When the committee met again on 1 June, he dispensed with any of Stimson's qualifications. According to the minutes:

\section{'VI Use Of The Bomb:}

Mr. Byrnes recommended, and the committee agreed, that the Secretary of War should be advised that, while recognizing that the final selection of the target was essentially a military decision, the present view of the Committee was that the bomb should be used against Japan as soon as possible; that it be used on a war plant surrounded by workers' homes; and that it be used without prior warning. ${ }^{8}$

One of the reasons Byrnes felt free to speak so forcefully on the issue is that he would have known that Truman, instinctively, was also supportive of using the bomb against Japan as soon as it was ready. Unlike Roosevelt, who seemed to become more and more enigmatic about the atomic bomb's use the closer it came to being a reality, ${ }^{9}$ Truman was more openly supportive about dropping the bomb and even seemed slightly energized by the prospect of using the new weapon. He made no ethical comments about the weapon, except just before it was used when he wrote in a diary that it should not be used against women and children. ${ }^{10}$ However, he made no order to that effect, and when the first bomb was dropped on Hiroshima, he celebrated with gusto. ${ }^{11}$

Thus, the civilian leadership was far more unified in favour of using the weapon and the civilian leadership, led by Truman, ultimately gave the go ahead for its use. This is particularly important because, had it been up to the US military led by the joint chiefs, the atom bomb might never have been used. The truth of the matter was that Leahy, Marshall, King and Arnold were all, to some degree, hesitant to use the atom bomb. ${ }^{12}$ The chiefs, and many other senior military personalities such as Generals Dwight Eisenhower and Douglas MacArthur and admirals Chester Nimitz and William Halsey all argued, mostly after the war it must be said, that dropping the atom bomb was either unnecessary or wrong. ${ }^{13}$ Within the chiefs there was a realization that the dropping of the bomb could shape the victory and the post-war world.

King and Arnold: The Soft Middle 
Though all the chiefs had some doubts, they approached the issue of the use of the atom bomb and the end of the war from quite different perspectives. The two most difficult to pin down, partly because their post-war stance conflicted with the contemporary record from May-August 1945, were King and Arnold. Both made negative comments about the atom bomb after the war, but there is little, if any, indication that they either held those views or tried to put them into action while the war was ongoing.

Ernest King was the most enigmatic. There is no useful record of King saying anything about the atomic bomb before Hiroshima and Nagasaki were attacked, though he first was given information about the Manhattan Project in $1943 .{ }^{14}$ He never attended the Interim Committee and there seem to be no minutes kept of a JCS meeting during which the bomb was discussed. ${ }^{15}$ After the war, King was only slightly more forthcoming. He was quoted not long after the war saying that he did not like 'any part of' the atomic weapon. ${ }^{16}$ This has been used by a number of scholars to claim King was opposed to the attacks. ${ }^{17}$ However, this claim rests on very light evidence. It is probably best to say that King had doubts about the bomb, but was happy to stay out of the discussions and as such tacitly gave consent. In his private papers there are pages and pages of notes that he assembled to help write a memoir. They have stories ranging from the most mundane to the highest levels of grand strategy in the war. ${ }^{18}$ Yet in none of them does he address the question of the atom bomb in any detail. Only in the memoir itself, which he wrote (in the third person) with the assistance of a reserve naval officer, did King provide any meaningful glimpse into his thinking-and in an extremely short meditation. He was very negative about the use of the bomb, though more on the grounds of necessity than ethics.

'The President in giving his approval for these attacks appeared to believe that many of thousands of American troops would be killed in invading Japan, and in this he was entirely correct; but King felt, as he had pointed out many times, that the dilemma was unnecessary one, for had we been willing to wait, the effective naval blockade would, in the course of time, have starved the Japanese into submission through lack of oil, rice, medicines, and other essential materials. The Army, however, with its underestimation of sea power, had insisted upon a direct invasion and an occupational conquest of Japan proper. King still believes this was wrong. ${ }^{19}$

Of all the statements made by members of the joint chiefs about their general view of the atom bomb and the end of the war against Japan, this might be the most problematic. King is absolutely right in pinpointing that the discussion over the atom bomb cannot be seen in isolation, it was part of a larger debate about whether Japan should be invaded or not. The atom bomb itself was not successfully tested until July 16 , and until then there was a real doubt as to whether the weapon 
would work and even if it did, how destructive it would turn out to be. As such, before July 16 there was an ongoing discussion over a possible invasion of Japan by US ground forces, starting with the main southern island of Kyushu. This invasion talk complicates the ethical strategic discussion, as any invasion held out the possibility of high casualties amongst both US and Japanese military personnel. It also held out the possibility of a high number of Japanese civilian deaths, even more than occurred during the bombing of Hiroshima and Nagasaki. ${ }^{20}$

However, King's claim that he had consistently argued against any invasion of Japan is deceptive. He might have opposed an invasion of Honshu, Japan's largest island, but he made a strong case for the invasion of the southernmost island, Kyushu. In June 1945, when discussion over the invasion reached a fever pitch, he spoke clearly in support of an assault on Kyushu. ${ }^{21}$ There was a famous meeting in the White House on June 18 involving Truman, the joint chiefs (though Arnold could not make it and was represented by General Ira Eaker), Stimson and the secretary of the navy, James Forrestal. During this meeting, King spoke strongly in favour of an invasion of Kyushu, indeed he sided with Marshall who painted a generally rosy picture of the casualties the USA would suffer in any such operation. King also claimed that seizing Kyushu would provide the USA with real strategic advantages.

'Admiral King agreed with General Marshall's views and said that the more he studied the matter, the more he was impressed with the strategic location of Kyushu, which he considered the key to success of any siege operations....It was his opinion that we should do Kyushu now, after which there would be time to judge the effect of possible operations by the Russians and the Chinese. ${ }^{22}$

King's post war comments about his supposed reluctance to use either the bomb or invade Japan, therefore, need to be taken with a large grain of salt. They are an indication that he was probably the least ethically engaged member of the JCS when it came to the use of the atom bomb and the end of the war against Japan. The opposition that he mentioned after the war, instead, had everything to do with proving the truth of his vision about the importance of sea power. It says a lot about the person. King fought the entire war trying to show the importance (and independence) of the United States Navy, as such he was often opposed to cooperating closely with either the American Army or the British Navy. He was worried, at the end of the war, that the atom bomb would overshadow what he believed was the US Navy's decisive contribution to victory in the war against Japan. 
Arnold, the head of the air force, had partly similar, partly different motivations. He had a rather unusual place in the JCS structure. As the USAAF was still part of the army, Arnold was actually Marshall's subordinate and was usually careful to support Marshall's positions in larger meetings. However, Marshall was far more interested in tactical airpower over strategic, and was sceptical about the USAAF's claims about the efficacy of the latter. ${ }^{23}$ As such, heand allowed Arnold huge latitude in the control of air force operations. ${ }^{24}$ Both Leahy and King also were also more than happy to treat Arnold as an equal member of the JCS and rarely questioned him on questions of air strategy. ${ }^{25} \mathrm{Arnold}$ was the member of the JCS who seemed most motivated by thoughts of revenge against the Japanese. Members of his aircrews were being publicly executed by the Japanese in 1944 and 1945, as the US strategic bombing campaign started to lay waste to Japanese cities. During his trips to the Pacific, he heard stories of these executions and other horrific war crimes committed by the Japanese, reacting emotionally. ${ }^{26}$ One would have thought that this would have made Arnold central to the debate over the atomic bomb, as it was clear that the new weapon would have to be delivered by one of Arnold's strategic bombers.

However, Arnold, even though he knew of the Manhattan Project from its beginning, only mentioned the bomb's existence just before it was used and when he did so, remained coy as to his own views. Some of this was due to his weak heart. For significant stretches between 1943 and 1945 Arnold had to take leave after suffering a series of heart attacks. He missed the important White House meeting on 18 June because he felt he could not rush back from a visit he was making to the Pacific theater. He did not want to put his heart under too much pressure.

Like King, however, he was also conflicted about the atomic bomb because he did not want to detract from what he saw as the USAAF's specific role in ending the war against Japan. Arnold was a great believer in the power of strategic bombing and had specifically put General Curtis LeMay in charge of the air force's campaign against Japan. LeMay, with Arnold's full backing, had controversially turned to the firebombing of Japanese cities. ${ }^{27}$ Arnold definitely wanted it seen that the air force had already done the major job weakening Japan before either the atom bomb was dropped or an invasion took place. ${ }^{28}$

Unlike King, however, Arnold was involved in the final process of the decision to drop the bomb, which took place during the famous Potsdam Conference in late July 1945. Of course, he was still careful about the words that he used in his diary. On 23 July he met with Stimson to confer on what he called the 'ultra' bombing effort. ${ }^{29}$ The two discussed a wide range of issues including whether the bomb would force the Japanese to surrender, how it would affect Japanese psychology and what kind of effect it would have on the communities around the target. After meeting with Stimson he 
wrote, enigmatically; 'Some day someone will dissolve the atom, release the atomic forces and harness the resultant terrific power as a destructive explosive. When?'30

The next day Arnold received a detailed update on the plans to drop the atom bomb. ${ }^{31}$ It contained all the information that he needed including the targets, the method of delivery (B-29 bombers) and the type and estimated time of the attack (between 1-10 August). Four cities were listed as possible targets, with Hiroshima and Nagasaki the highest priorities. Both were described as large industrial cities, with the implication that they had large civilian populations. There was even an interesting side note to the effect that it was thought that a large number of Japanese industrialists and political figures had taken refuge in them as they had heretofore not been heavily attacked.

So it was certainly clear to Arnold that a large number of civilians would be killed in the attacks. This bothered him little, if at all, at the time, and he was happy to allow his deputy, General Carl Spaatz to be given operational control of the bombs. ${ }^{32}$ Spaatz was serving as the head of all US strategic bombing forces, and it was once the weapon was released to his overall control that the clock started ticking towards the attack on Hiroshima. He was actually far more open than Arnold in his doubts about dropping the bomb, and requested a written order before he agreed to implement the plan to cross the atomic threshold. ${ }^{33}$

Arnold's true feelings about the bomb also become complicated by his immediate and longer term reactions to the attacks on Hiroshima and Nagasaki. When the first confirmed news was received that the attacks were successful, Arnold was positive, agreeing that they were proper payback for the suffering that the Japanese had inflicted on American prisoners of war. ${ }^{34}$ However, as time went by, some have argued that Arnold's view on the atom bomb became more negative..$^{35}$ Others, however, dispute this. ${ }^{36}$

What seems hard to support is the idea that Arnold had a strong ethical objection to the bomb. When he did speak negatively, it was to stress that Japan was already defeated, the implication being that the bomb was not necessary to force them to surrender. It seems more of a need to show how much the USAAF had already done to drive Japan out of the war then to imply that an ethical wrong had been committed. In Arnold's memoirs, for instance, there is no discussion of him being opposed to the dropping of the atomic bomb on ethical grounds. The most important point that he seems keen to make in his memoirs was that the atom bomb had to be delivered by aircraft. ${ }^{37}$

There might, as in the case of Ernest King, have been a residual doubt in his mind about whether the United States should have crossed the atomic threshold, but this cannot obscure the fact 
that for the last few weeks in July Arnold was involved in the command decisions about the use of the bomb, and was willing to let the plan go ahead without objection.

\section{Marshall and Leahy: The Hard Poles}

If King and Arnold present somewhat obscure and complex reactions to the idea of atomic warfare in 1945, the two most powerful members of the joint chiefs, Marshall and Leahy, present clearer, contrasting pictures. By this time in the war they were the yin and yang of American grand strategy. Between 1942 and 1945 they had often argued for diametrically different ways of war. Marshall favored a large-army strategy, based on attacking Germany first with a landing in France as soon as possible and, after that, an invasion of Japan as soon as one was practicable. Leahy, on the other hand, had a more economic and indirect notion of how victory would be won. He wanted the Allies to concentrate on establishing complete air and sea supremacy in both Europe and the Pacific, and then once having choked them off, compel German and Japanese surrender. Within this vision was Leahy's belief that American casualties and attacks on civilian targets should be kept to an absolute minimum.

This meant that Leahy and Marshall fought over not only the atom bomb in the spring and summer of 1945, but also about the need to invade Japan. Marshall's views were those of a direct soldier. Within the Joint Chiefs he was the most aggressive in pressing for Truman to authorize the plan for the Kyushu attack (codenamed Olympic). ${ }^{38} \mathrm{His}$ arguments for Olympic were initially based on somewhat optimistic casualty projections. During the meeting in the White House on 18 June, Marshall opted to present to the president the rosiest possible picture of expected US casualties for Olympic, approximately one American casualty for each 5 Japanese soldiers to be fought. ${ }^{39}$ It is important to see Marshall being so optimistic about casualties, because this contradicts one of his most famous statements about dropping the atomic bombs, that it was done to save half a million US casualties.

Because of Marshall's seniority in the War Department, of all the chiefs he played the most prominent official role in the decision on whether and how to use the atom bomb. While not a standing member of the Interim Committee, Marshall was invited to attend during two of its most important meetings, those on 31 May and 1 June. Marshall was invited specifically because Truman had asked that he be involved in making the final decision on the use of the bomb. ${ }^{40}$ Marshall had known of the atomic bomb program from the start, and therefore had already given a good deal of thought to how it could be integrated into his strategic vision. Two days before he attended the first interim committee meeting, he had a detailed discussion on precisely this question with assistant 
secretary of war, John McCloy. McCloy recorded Marshall's thoughts, and demonstrated that the general saw the atom bomb as a new weapon, which shared some ethical and strategic similarities with poison gas, but which, crucially, was a legitimate weapon of war to be used if the US government decided it was needed to end the conflict.

'General Marshall said he thought these weapons might first be used against straight military objectives such as a large naval installation and then if no complete result was derived from the effect of that, he thought we ought to designate a number of large manufacturing areas from which the people would be warned to leave-telling the Japanese that we intended to destroy such centers. There would be no individual designations so that the Japs would not know exactly where we were to hit-a number should be named and the hit should follow shortly after. Every effort should be made to keep our record of warning clear. We must offset by such warning methods the opprobrium which might follow from an ill considered employment of such force.

The General then spoke of his stimulation of the new weapons and operations people to the development of new weapons and tactics to cope with the care and last ditch defense tactics of the suicidal Japanese. He sought to avoid the attrition we were suffering from such fanatical but hopeless defense methods-it requires new tactics. He also spoke of gas and the possibility of using it in a limited degree, say on the outlying islands where operations were now going on or were about to take place. He spoke of the type of gas that might be employed. It did not need to be our newest and most potent-just drench them and sicken them so that the fight would be taken out of them - saturate an area, possibly with mustard, and just stand off. He said he had asked the operations people to find out what we could do quickly-where the dumps were and how much time and effort would be required to bring the gas to bear. There would be the matter of public opinion which we had to consider, but that was something which might also be dealt with. The character of the weapon was no less humane than phosphorous and flame throwers and need not be used against dense populations or civilians-merely against these last pockets of resistance which had to be wiped out but had no other military

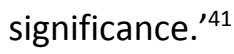

It was certainly one of the most important reflections given by a US military leader on the bomb (and weapons of mass destruction as a whole) during the war. It has been used occasionally to say that Marshall had doubts about the use of atomic weapons. However the most revealing thing was Marshall's surprising willingness to contemplate using weapons such as the atom bomb and gas. During the war, all the major powers debated whether they should use gas attacks, though in the end 
no one was willing to do so against another major power (there were examples of the Japanese using different gasses in their brutal war against the Chinese). ${ }^{42}$ Marshall, however, was the most senior American who seemed most supportive of using gas if it was thought practicable. Two weeks after he spoke to McCloy, Marshall sent King an Army memorandum which called for the pre-emptive use of chemical warfare against the Japanese during Olympic. ${ }^{43}$

In fact, it was Marshall who from that moment provided the most consistent support for the use of atomic weapons. During the two meetings of the interim committee which he attended-the ones which determined the direction of weapons usage and during Byrnes claimed that a consensus had been reached that the atom bomb should be used without warning on an industrial target that contained a large number of worker's houses-Marshall seemed completely comfortable with the idea that the bomb would be used. ${ }^{44}$ During the 31 May meeting, he spoke almost entirely on the atomic bomb's place in US-USSR relations. ${ }^{45}$ During the 1 June meeting, the one in which Byrnes made his comment about their being a strong consensus on using the bomb, Marshall was silent. ${ }^{46}$

In the run up to the use of the bomb Marshall's silent acceptance moved to a far more active assent. By the time of Potsdam, Marshall was eager to use the atom bomb. He had no faith that strategic bombing would end the war on its own, and finally understood that the invasion of Japan would now be far bloodier than he had claimed in June. ${ }^{47} \mathrm{He}$ admitted (indirectly) to Truman that his earlier assumptions of relatively light losses from an invasion of Japan were wrong, and was now telling the president that it might cost half a million US casualties to force the Japanese to surrender by invading and conquering the home islands. ${ }^{48} \mathrm{He}$ was so worried about the resistance the Japanese could pose that he started considering using the atomic bomb as a tactical weapon against Japanese troops on Kyushu. ${ }^{49}$ Thankfully such a disastrous move never occurred.

After the war, Marshall continued with his strong support for using the atomic bomb. He provided more detail than he ever had previously in some interviews given to his biographer, Forrest Pogue, not long before his death. By this time, Marshall was more than happy to describe the use of the atomic bomb as 'wise.'

'Q. 71. Do you feel it was necessary to drop the bomb to shorten the war?

A. I regarded the dropping of the bomb as of great importance and felt that it would end the war possibly better than anything else, which it did, and I think that all the claims about the bombings and all afterwards were rather silly. Because we had had these terrific destructions and it hadn't had these effects. I think it was quite necessary to drop the bombs in order to shorten the war. 
Q. 72. Do you feel in retrospect that it would have been better to refrain from using it?

A. In retrospect, I feel the same way about it. There were hundreds and hundreds of thousands of American lives involved in these things as well as hundreds of billions of money. They had been perfectly ruthless. We had notified them of the bomb. They didn't choose to believe that. And what they needed was shock action and they got it. I think it was very wise to use it. ${ }^{50}$

If Marshall represented the most clear-cut example of someone who supported the use of the atomic bomb, Leahy represented the most clear-cut example of someone who was opposed. . Leahy was Marshall's superior, not only in position as chairman of the joint chiefs, but also in rank, having been promoted to the 5 -star level one day before the general. ${ }^{51}$ Leahy had a remarkable position in the US government during the war. As the president's chief of staff, he was the only policy-making individual who had daily, direct access to the Oval Office. He was also, along with Harry Hopkins, the only individual who had complete access to Roosevelt's and Truman's correspondence with world leaders such as Winston Churchill and Joseph Stalin. ${ }^{52}$

Leahy's role in the atomic bomb decision has been rather poorly understood, partly because Marshall liked to pretend he was more powerful than he really was. After the war Marshall claimed that Leahy was only let in on the atomic secret late in the day, not long before the successful test of the weapon in July $1945 . .^{53}$ Nothing could be more untrue. Leahy would have been told about the atomic bomb by Roosevelt, his close personal friend, almost immediately after he became FDR's chief of staff in July 1942. In fact, as time came on Roosevelt saw Leahy as the only person he could fully trust with America's atomic secrets. This was made explicitly clear in September 1944, when Roosevelt invited Churchill to a meeting in Hyde Park NY (the president's family home) to discuss atomic policy. During these top secret meetings the only people in the room were often Roosevelt, Churchill and Leahy. ${ }^{54}$ Marshall was kept far away from Hyde Park during this, and all other meetings during the war. $^{55}$

The problem we have with Leahy was the same with which Marshall was presented. Leahy was discrete and so close to the president that he rarely had to write things down. Before Roosevelt died, Leahy spent a good deal of his time trying to shape FDR's opinion about the bomb-in a negative direction. He complained about its cost, predicted it would not work, and believed it was immoral. We know this because he mentioned his beliefs to one of the few people in the US government he trusted, H. Freeman Matthews. Matthews had worked with Leahy when the latter was the US ambassador to 
Vichy France in 1941. In 1944-1945 he was head of the State Departments Western European desk before becoming Under Secretary of State.

Matthews was one of the few people with whom Leahy is recorded as discussing the atomic bomb, and it was clear not only did Leahy hope it would not work, he believed it would be a tragedy if it did and the USA then used it against an enemy. He told Matthews before it was tested that 'I don't think this thing is going to work, this bomb. But...if it does, it's going to have terrible, terrible consequences for the future. ${ }^{56}$ Matthews was struck by the intensity of Leahy's loathing for the atom bomb, writing in his unpublished memoirs that the admiral was convinced that the bomb was a 'terrible thing for the world. ${ }^{157}$

The problem Leahy had was trying to keep the bomb from being dropped once Roosevelt had died. He was not a close friend of Truman and the new president listened to other advisers, such as Byrnes and Marshall, as much if not more than he did to Leahy. That did not stop the admiral from trying. He was in the room when Truman was given his first detailed briefing about the atomic bomb program's existence and when he and Truman first discussed the weapon, Leahy was very negative. He told the president that it was '...the biggest fool thing that we have ever done. ${ }^{58}$ Truman, however, was unmoved by Leahy's negativity and the admiral was not made a member of the interim committee. Byrnes did, however, keep him abreast of developments, paying two evening visits to Leahy's Washington DC townhouse to discuss atomic policy with him. ${ }^{59}$

What also makes Leahy's position unusual was that he strongly opposed dropping the bomb and invading Japan at the same time. This position, which might have seemed contradictory, was based on a consistent ethical stand that he had shown for much of his career. Starting with his first experience of combat, back in the Spanish-American War of 1898, Leahy maintained that the United States should not wage war against civilian targets. ${ }^{60}$ During World War Ilwar he continued this position, though it must be said that there was a certain amount of self-deception in his approach. He believed the USAAF when they claimed that they were doing 'precision' attacks against Axis targets. ${ }^{61}$ Only when he attended the Potsdam Conference in July did he see the true devastation that had been inflicted by strategic bombing. Leahy's heartfelt opposition to the use of the atom bomb came from the strength of his ethical convictions, which he admitted overrode his more logical side. As he told a close aide '...deep in the heart, I don't like to see weapons like that developed and used. ${ }^{62}$

As a sign that Leahy's lobbying might have been playing in Truman's mind, it was only after the president and his chief of staff arrived for the Potsdam Conference that Truman wrote in his diary that he did not want the atom bomb used against women and children. 
If seeing the devastation in Germany only reconfirmed Leahy's opposition to the use of the atom bomb, he was left with the basic conundrum that the same ethical standard which had him opposing the bomb also led him to argue against any invasion of Japan. Leahy believed that with Japan completely cut off from the rest of the world by US air and sea power, the war was over and the Japanese government would have to surrender-sooner rather than later. As the war was over in his mind, the idea of invading Japan to possibly hasten its end seemed pointless; further slaughter and the death and maiming of hundreds of thousands on both sides that would make little material difference to the war's outcome. It was why he led the opposition to the invasion of Kyushu on 18 June and continued afterwards to impress on the president the terrible cost any such attack would incur.

In many ways he succeeded too well in this task, and made Truman even more eager to use the bomb when it was shown to be operable. Leahy's overall position would have been politically very difficult for Truman to take (were the president even inclined to do it-which he was not). Truman wanted the war to be over, and if the atom bomb offered him an opportunity to speed up that process, he was darn sure he was going to take it.

When the bomb was dropped Leahy suffered a severe depression. He remarked to those closest to him that the United States had committed a grave ethical mistake, as war was never to be waged directly against civilian targets. ${ }^{63}$ To some who knew him, the regret he felt at the bomb's use was so great it represented the moment when his robust health first started to give way. In his memoirs, written 5 years later, he could not contain his regrets. He stated outright that in using the bomb the United States 'had adopted an ethical standard common to the barbarians of the Dark ages. I was not taught to make war in that fashion, and wars cannot be won by destroying women and children. $^{64}$

\section{The Atom Bomb, the End of the War and the Lost Victory}

Writing in 1949, Arnold decried what he saw as the failure of victory in the Second World War to bring a true peace. 'One thing stands out clearly against the background of my experience: the winning of peace is much more difficult than the winning of even a global war. One look at the condition of the poor old world today, four years after the supposed ending of World War II, almost makes me gasp. Where is our peace?'65 Arnold was giving voice to a feeling that was shared by most of the joint chiefs (and many others). The war was supposed to lead to a longstanding and solid period of peace, and yet within years relations between the USA and the USSR had deteriorated so dramatically that an even more destructive, nuclear war, seemed a real possibility. Leahy, who played 
a very important role in determining US policy during the Cold War, was maybe even more depressed. 'Victory' to him meant far more than conquering Japan and Germany. As he surveyed the world, he believed that the United States was and would continue 'paying for this war in many ways long after we, and our children too, had passed away. It may require the better part of a century to bind up the wounds of a world torn in its physical structure by forces which were unleashed first by the aggressor nations and then by us. ${ }^{66}$

It might be surprising to see the chiefs being so ambiguous about the meaning of victory in the war. They had done their job. Germany and Japan had been completely conquered, their armed forces destroyed, and their ability to threaten the United States nullified. Yet, the war was supposed to be more than this, and by a higher standard it fell short. There were two specific ways this was tied to the atomic bomb decision. The first was the meaning of the bomb in the post-war world, and this was what most preoccupied Leahy. What Leahy was most worried about was that if the USA used the bomb in a first strike attack, it would make it far more likely that it would suffer similarly in the coming years or decades once other powers also developed atomic weaponry. He wanted the USA to send a message to the world that the atom bomb was such a terrible weapon (in his mind morally equivalent or even worse than poison gas) that it should not be used even if it was being targeted on a country that had no retaliatory capability. After the war he continued his crusade against atomic weapons. He wrote one of the first detailed definitions of weapons of mass destruction in the US government. ${ }^{67}$ Until he left office in early 1949 he did his best to ensure that the USA did not have a formally approved first strike atomic policy.

Then there was the question of the meaning of the bomb, victory and the Cold War. Where the chiefs were different from many in the civilian hierarchy, most prominently Byrnes, was that even those who supported using the bomb had no desire that it be seen as a weapon against the USSR, a way to use 'victory' to intimidate the Soviets. They saw victory as being over Naziism and Imperial Japan. They were less engaged with starting a new competition with the USSR. Though they had some differences in their views of the atom bomb, they had little or no interest in using the bomb to start a competitive new era over the USSR, to manipulate victory as part of an early Cold War. This difference, perhaps more than any other, showed the difference of the military mind from the civilian.

In the end two very important differences stand out between the military and the civilian leadership. Compared to Truman, Byrnes and Stimson-Leahy, Marshall, King and Arnold had not only a wider range of opinion they had, perhaps most surprisingly, more doubts about the use of the bomb. Three of the four mentioned different concerns about the bomb after the war and one, Leahy, spoke out against it before it was dropped. Their opposition emerged from different impulses; ethical, 
practical and to a certain degree selfish. Arnold and King, for instance, were both concerned with protecting the reputation of their branch of the armed service in causing the defeat of Japan. They did not want the atom bomb to obscure what they believed were the decisive roles of the USAAF and USN in bringing Japan to defeat. Both also had some ethical doubts about using the weapon, and were certainly uneasy discussing it after the war. However, in both cases it is important not to overstate the ethical component in their thinking. Leahy on the other hand, had enormous ethical problems with dropping the bomb, and publicly aired them in his memoirs which were published not long after he left office. In fact, Leahy was the person at the upper echelon of the US government most opposed to the use of atomic weapons. No civilian matched the intensity or duration of his opposition. Even Marshall, who was the most robust in arguing for the use of the atomic bomb (and that of poison gas) was found to have made qualifying comments a few months before Hiroshima, in which he said the bomb should first be used on a strictly military target and only later be used to attack civilians if the Japanese had still not surrendered.

Why did the military debate differ so from the civilian and what did it have to say about the end of the war? To begin with, the debate showed that the military, or at least some of its leadership at the JCS level, did not see the Second World War as a war which would automatically transform the USA into a permanent global police force. They were much more concerned with the defeat of the Axis Powers, and in protecting what they saw as the reputation of the United States and its armed services for fighting wars properly and effectively in doing so. They had little interest in making a grand global statement about American power, to intimidate, for instance, the USSR. In other words, again it was the military leadership of the United States that was least likely to see the world war mutating quickly into a Cold War. In this way the Joint Chiefs present a very different debate from that which has obsessed many historians for the past decades. Intimidating the Soviet Union had only miniscule impact on their thinking. They rarely, if at all, connected the bomb to an attempt to limit Soviet expansion. Only George Marshall ever addressed the question before the attacks on Hiroshima and Nagasaki, and even he did it in a non-commital way. Certainly compared to Byrnes or even Truman, the military leadership of the United States was more restrained and less aggressive when it came to planning for the post-war world.

It leaves us with one of the great questions about the end of the war. Had the US military had its way, the war might have ended very differently. The bomb might not have been dropped and the war could have continued on for months longer until either an invasion of Kyushu, the entry of the USSR into the conflict or even an extended air-sea blockade would have forced the Japanese to surrender. The atomic threshold would not have been crossed, but on the other hand, far more 
Japanese, both military and civilian, would have died had an invasion or extended blockade occurred. There is no easy answer in this debate, as there was no easy answer at the time.

\footnotetext{
${ }^{1}$ Much of the vast literature which delves into the Truman administration's decision to employ the atom bomb, falls into three large groupings. The traditionalists/orthodox historians argue that the atom bomb was needed to force Japanese surrender, prevent a bloody invasion of Japan, and save many tens, if not hundreds
} of thousands of US and Japanese lives. Some of the best examples include: Wilson Miscamble, The Most Controversial Decision: Truman, the Atomic Bombs and the Defeat of Japan, (Cambridge, Cambridge Univ Press, 2011); D. M. Giangreco, Hell to Pay: Operation Downfall and the Invasion of Japan 1945-1947, (Annapolis, Naval Institute Press, 2009); Robert James Maddox, Weapons for Victory: The Hiroshima Decision, (Columbia, Univ Missouri Press, 2004); Richard B. Frank, Downfall: the End of the Imperial Japanese Empire, (New York, Penguin, 2001). Opposed to this group are the revisionists. They argue that the bomb did not need to be dropped as Japan was already close to surrender and that any US invasion of japan was not necessary or if it had to go ahead that it would have resulted in far fewer casualties than the traditionalists argue, and that the bomb was either mostly or partially aimed at intimidating the USSR. Some of the best examples include: Campbell Craig and Sergey Radchenko, The Atomic Bomb and the Origins of the Cold War, (New Haven, Yale Univ Press, 2008); Kai Bird and Lawrence Lifschultz (eds), Hiroshima's Shadow, (Stony Creek, The Pamphleteers Press, 1998); Gar Alperovitz (et al), The Decision to Use the Atomic Bomb: And the Architecture of an American Myth, (New York, Alfred Knopf, 1995); Gar Alperovitz, Atomic Diplomacy: Hiroshima and Potsdam, The Use of the Atomic Bomb and American Confrontation with Soviet Power, (New York, Vintage, 1965). There is a middle ground, that argues that the bomb was really dropped to try and force the Japanese to surrender, not to intimidate the Soviets, but that the Japanese probably would have surrendered relatively quickly anyway, certainly not long after the Red Army attacked. For some of these analyses see: J. Samuel Walker, Prompt and Utter Destruction: Truman and the Use of Atomic Bombs against Japan, (Chapel Hill, UNC Press, 1997); Kenneth P. Werrell, Blankets of Fire: US Bombers over Japan during World War II, (Washington, Smithsonian Institute Press, 1996). Walker has also published a very useful historiographical article on the different schools of thoughts: J. Samuel Walker, 'Recent Literature on Truman's Atomic Bomb Decision', in Frank Costigliola and Michael J, Hogan (eds) America in the World: The Historiography of American Foreign Relations since $1941 \mathrm{~m}$ (Cambridge, Cambridge Univ Press, 2014). Walker does an excellent job summarizing the different arguments on the bomb and shows the strength of a middle ground position between the more hard line traditionalists and revisionists. For an overview of some of the ethical views of the dropping of the bomb see: Francis X. Winters, Remembering Hiroshima: Was it Just, (Farnham, Ashgate, 2009).

${ }^{2}$ One of the best books about the Joint Chiefs is: Mark A Stoler, Allies and Adversaries, The Joint Chiefs of Staff, the Grand Alliance, and US Strategy in World War II, (Chapel Hill, UNC Press, 2000). Stoler spends only a little time discussing the different joint chiefs and the decision to use the atomic bomb (see pp. 256-7).

${ }^{3}$ Ernest J. King and Walter Muir Mitchell, Fleet Admiral King: A Naval Record, (London, Eyre and Spottiswoode, 1953), pp 411-12.

${ }^{4}$ Harry S. Truman, Memoirs: Volume One, Year of Decisions, (Garden City, Doubleday, 1955) p. 418.

${ }^{5}$ Truman actually invited Stimson to attend the Potsdam Conference in July 1945, but by the time the meetings started he had decided he could do without the Secretary of War's advice and kept Stimson off the official American negotiating team.

${ }^{6}$ Sean L. Malloy, Atomic Tragedy: Henry L. Stimson and the Decision to Use the Atomic Bomb against Japan, (Ithaca, Cornell Univ Press, 2018), pp 115-16. Malloy described Stimson's conflicts over the bomb in detail, and argues that ultimately he accepted that it could be used on large Japanese city (as long as it was not Kyoto) partly because the shock value could lead to a Japanese surrender. According to one of Stimson's biographers, 
the Secretary of War always assumed the bomb would be dropped, so never really contemplated holding back. Elting E. Morison, Turmoil and Tradition: A Study of the Life and Times of Henry L. Stimson, (Boston, Houghton Mifflin, 1960), p. 629.

7 'Notes of the Meeting of the Interim Committee, 31 May 1945', pp 13-14. Accessed online through the Truman Library:

https://www.trumanlibrary.org/whistlestop/study_collections/bomb/large/documents/index.php?documenti $\mathrm{d}=39$ \&pagenumber $=14$

8 'Notes of the Meeting of the Interim Committee, 1 June 1945,' pp. 8-9. Accessed online through the Truman Library:

https://www.trumanlibrary.org/whistlestop/study_collections/bomb/large/documents/index.php?documenti $\mathrm{d}=40$ \&pagenumber $=8$

${ }^{9}$ Roosevelt said very little about the bomb the closer it came to being a reality. After his meetings with Churchill in October 1944, he was reluctant to discuss its use. One of the few things he said about it was that it might be used against Japan, but only in a demonstration over an uninhabited area. See: Ronald Takaki, Hiroshima: Why America Dropped the Bomb, (Boston, 1995) pp 20-1; Gar Alperovitz, The Decision to Use the Atomic Bomb and the Architecture of an American Myth, (London, 1995) p. 662

${ }^{10}$ This was in a series of pages of notes that Truman kept during Potsdam. The entry about not attacking women and children was dated 25 July 1945. The document can be accessed at: http://www.trumanlibrary.org/whistlestop/study collections/bomb/large/documents/pdfs/63.pdf\#zoom=100 ${ }^{11}$ Arnold A. Offner, Another Such Victory: President Truman and the Cold War 1945-1953, (Palo Alto, Stanford Univ Press, 2002), p. 92

12 In: Alperowitz, The Decision to Use the Atomic Bomb (1995), there are large sections on all the different military personalities that expressed some opposition to the use of the atomic bomb. It is useful, but at times lacks nuance as it ascribes a rather one dimensional nature to their thinking. See pp. 329, 334-5, 348 for some mentions of King and Arnold. From these one would assume that they were more clearly opposed to the use of atomic weapons than they probably were.

${ }^{13}$ Eisenhower, Nimitz and Halsey all spoke negatively about the use of the atom bomb, in an ethical sense. They not only believed that the weapon was unnecessary to end the war, they also believed that it was morally wrong for the United States to have used the weapon in the first place.

${ }^{14}$ Thomas B. Buell, Master of Sea Power: A Biography of Fleet Admiral Ernest J. King, (Annapolis, Naval Institute Press, 1980), p. 496

${ }^{15}$ For instance, between 1 March 1945 and the attack on Hiroshima, which would have been the period if any during which the atomic bomb would have been mentioned, there is no minuted discussion of it in any of the JCS minutes. During that period the JCS met on: 1 March, 13 March, 27 March, 24 April, 22 May, 12 June, 18 June, 26 June, 16-21 July (as part of Potsdam Conference), 23 July.

${ }^{16}$ Buell, Master of Sea Power, p. 497.

${ }^{17}$ Ronald Schaffer, Wings of Judgement: American Bombing in World War II, (New York, OUP, 1985), p. 166; Alperovitz, The Decision to Use the Atomic Bomb, p. 329.

${ }^{18}$ Ernest King Mss, Library of Congress Manuscript Division, Washington DC, Box 35 has over 100 pages of different notes that King put together after the war. There does not seem to be a mention of the atom bomb anywhere in them.

${ }^{19}$ King and Whitehill, Fleet Admiral King, A Naval Record, (London, 1953), p. 412.

${ }^{20}$ The weakest argument made by the revisionists against the atomic bomb was that the casualties that would have been incurred during any such operation would have been on the lighter side: (see Barton Berstein, 'A Postwar Myth: 500,000 US Lives Saved'. Bulletin of the Atomic Scientists, \#42, (June/July 1986), pp 38-40; John R. Skates, The Invasion of Japan, Alternative to the Bomb, (Columbia, 1994), pp 76-80). It was also an unnecessary diversion from the most important ethical argument against dropping the bomb, not that it precluded any invasion, but that no invasion was necessary because of US air and sea control around Japan. ${ }^{21}$ The minutes of this meeting are discussed in every serious work on the debate over invading Japan or using the atom bomb. For an online copy see: 'Minutes of Meeting held at the White House, June 18, 1945',

Accessed online through the Truman Library.

https://www.trumanlibrary.org/whistlestop/study_collections/bomb/large/documents/index.php?documenti $d=21$ \&pagenumber $=1$

22 Ibid, p. 4.

${ }^{23}$ John W Huston (ed), American Airpower Comes of Age: General Henry H. "Hap" Arnold's World War II Diaries, Vol 1, (Maxwell, Air University Press, 2002) pp 239-40 
${ }^{24}$ Richard G. Davis, Carl A. Spaatz and the Air War in Europe, (Washington, Centre for Air Power History, 1993). p. 496

${ }^{25}$ Phillips Payson O'Brien, How the War was Won: Air-Sea Power and Allied Victory in World War II, (Cambridge, Cambridge Univ Press, 2015). Chapter 4 has a discussion of the different members of the JCS and their interactions.

${ }^{26}$ Henry A. Arnold Mss, Library of Congress, Washington DC, Reel 3, Diary entry, 16 June 1945.

${ }^{27}$ Michael Sherry, The Rise of American Airpower: The Creation of Armageddon, (New Haven, Yale Univ Press, 1987) pp. 266-83.

${ }^{28}$ There is a meditation on Arnold's reasons for missing the 18 June meeting in the edited version of his diary. See: Huston (ed), American Airpower Comes of Age, , Vol 2, (Maxwell, Air University Press, 2002), pp. 318-19.

${ }^{29}$ Henry A. Arnold Mss, Library of Congress, Washington DC, Reel 3, Diary entry 23 July 1945.

${ }^{30}$ Henry A. Arnold Mss, Library of Congress, Washington DC, Reel 3, Diary entry 23 July 1945.

${ }^{31}$ John Stone to Arnold, 24 July 1945, Accessed online through the Truman Library:

https://www.trumanlibrary.org/whistlestop/study_collections/bomb/large/documents/index.php?documenti $d=31$ \&pagenumber $=1$

${ }^{32}$ Henry A. Arnold, Global Mission, (New York, Harper and Bros, 1949) p. 589. See also: Thomas M. Coffey, HAP: The Story of the US Air Force and the Man Who Built It, General Henry H. "Hap" Arnold, (New York, The Viking Press, 1982), p. 382.

${ }^{33}$ Schaffer, Wings of Judgement, p. 147.

${ }^{34}$ Ed Cray, General of the Army: George C. Marshall: Soldier and Statesman, (New York, Norton, 1990), p. 548.

${ }^{35}$ Dik Alan Daso, Hap Arnold and the Evolution of American Air Power, (Washington, Smithsonian Institute Press, 2000), p. 209.

${ }^{36}$ Coffey, HAP: The Story of the US Air Force, p. 371.

${ }^{37}$ Arnold, Global Mission, p. 233. Arnold discusses the atomic bomb on six pages in this memoir. The one mention of any opposition to the explosion of the bomb occurred when one of the scientists came to Arnold trying to have the test explosion stopped for the reason that they could not be sure how powerful the bomb would be (see p. 255).

${ }^{38}$ Truman, Memoirs: Volume One, p. 416.

${ }^{39}$ Frank Settle, General George C. Marshall and the Atomic Bomb, (Santa Barbara, Praeger, 2016), p. 92.. Settle describes Marshall as "evasive" during the meeting. Marshall claimed that the best comparison for Olympic was General MacArthur's campaign on Leyte, where US-Japanese casualties were running at a rate of 1 to 5 . There were far bloodier comparisons, including Okinawa and Iwo Jima, which were much closer to 1 to 2 or even 1 to 1.25. 'Minutes of Meeting held at the White House, June 18, 1945', Accessed online through the Truman Library.

https://www.trumanlibrary.org/whistlestop/study_collections/bomb/large/documents/index.php?documenti $d=21$ \&pagenumber $=1$

40 'Notes of the Meeting of the Interim Committee, 31 May 1945', p. 2.

41 'Memorandum of Conversation', 29 May 1945, McCloy Notes. Accessible through Marshall Foundation Online: http://marshallfoundation.org/library/digital-archive/memorandum-of-conversation/

${ }^{42}$ Yuki Tanaka, 'Poison Gas: The Story Japan would Like to Forget', Bulletin of Atomic Scientists, Vol 44, No 8 , 1988, pp 10-19.

${ }^{43}$ George Marshall Mss, George Marshall Foundation Library, Lexington VA, Marshall to King, 15 June 1945.

${ }^{44}$ Settle, George C. Marshall, pp 78-80.

45 'Notes of the Meeting of the Interim Committee, 31 May 1945', p. 11.

46 'Notes of the Meeting of the Interim Committee, 1 June 1945.' Marshall is listed as having attended the meeting, but there is no record of him speaking during its proceedings.

${ }^{47}$ Schaffer, Wings of Judgement, p. 166.

${ }^{48}$ Truman, Memoirs: Volume One, p. 417.

${ }^{49}$ Miscamble, The Most Controversial Decision, pp. 82, 116.

50 'Interview with General Marshall', Tape 14, February 11, 1957, p. 27; Accessed through Marshall Foundation online. http://marshallfoundation.org/library/wpcontent/uploads/sites/16/2014/05/Marshall_Interview_Tape14.pdf

${ }^{51}$ As a 5-star member of the navy Leahy was a Fleet Admiral, a rank he was given on 15 December 1944. Marshall was made the army equivalent, General of the Army, the following day.

${ }^{52}$ William Rigdon, White House Sailor, (Garden City, Doubleday, 1962), pp 6-9; See also: Elsey, An Unplanned Life, pp. 18-21. 
53 'Interview with General Marshall', Tape 14, February 11, 1957, pp. 26-27; Accessed through Marshall Foundation online. http://marshallfoundation.org/library/wp-

content/uploads/sites/16/2014/05/Marshall_Interview_Tape14.pdf

${ }^{54}$ William D. Leahy Mss, Library of Congress, Washington DC, Leahy Diary, 17-19 September, 1944. See also, Leahy, I Was There, pp. 264-6.

55 Marshall admitted in an interview after the war that he expected on a number of occasions that he would be invited to Hyde Park or FDR's winter retreat in Warm Springs Georgia, but that no invitation was ever issued.

"Interview with General Marshall", 11 February 1957, p. 18. Accessible through Marshall Foundation online on: http://www.marshallfoundation.org/library/wp-

content/uploads/sites/16/2014/05/Marshall_Interview_Tape14.pdf

${ }^{56}$ This comes from the $\mathrm{H}$. Freeman Matthews oral history interview on the Truman library website, http://www.trumanlibrary.org/oralhist/matthewh.htm , p. 6. (interview given 6 June 1973).

${ }^{57} \mathrm{H}$. Freeman Matthews Mss, Princeton University Archives, Princeton NJ, unpublished memoirs, p. 604.

58 Truman, Memoirs: Volume One, pp.10-11.

${ }^{59}$ William D. Leahy Mss, Library of Congress, Washington DC, Leahy Diary, 20 May 1945, 4 June 1945.

60 Leahy Diary, Vol I, pp 33-4.

${ }^{61}$ William D. Leahy, I Was There: The Personal Story of the Chief of Staff of Presidents Roosevelt and Truman Based on His Notes and Diaries of the Time, (New York, McGraw Hill, 1950), pp 395-6.

62 Bernard L Austin Oral History, p. 65, Naval History and Heritage Command Library, Washington DC.

${ }^{63}$ Henry A. Adams, Witness to Power: The Life of Fleet Admiral William D. Leahy, (Annapolis, Naval Institute Press, 1985), p. 299.

${ }^{64}$ Leahy, I Was There, p. 441.

65 Arnold, Global Mission, p. 265.

${ }^{66}$ Leahy, I Was There, p. 438.

67 William D. Leahy Mss, Naval History and Heritage Command, Washington DC, Leahy Memorandum for JCS, May 1947. 